\title{
A Imagem que Falta
}

Vinicius Esperança

O objetivo deste artigo é analisar diferentes narrativas e tentar reconstruir a partir de diferentes vozes a grande operação conduzida por instituições e agentes do estado, que culminou na ocupação militar do Complexo do Alemão. Não encontrei todas as vozes que seriam necessárias para a construção da imagem que gostaria de (re)construir. Quando escrevo isto, entretanto, percebo que poderia ter partido da falsa esperança de acreditar que aquele evento passado poderia ser reconstituído a partir de pedaços de memórias que, juntas, dariam luz àqueles dias passados. Como no ato de construir um mosaico, diferentes pedaços formariam, de acordo com o gosto do artista, a imagem que escolhera de antemão. Contudo, muito cedo, pude perceber que se empreendesse tal projeto estaria determinantemente condenado ao fracasso e ao falseamento daquilo que me propus a fazer. As muitas dificuldades na construção deste texto poderiam ter produzido tanto a desistência em sua feitura quanto a talvez desonesta opção por construir a imagem (literária) de um evento que nada mais seria que o reflexo ideológico da pessoa do etnógrafo. Não incorro na ingenuidade, no entanto, de tentar esconder que a imagem que esboço é imagem que eu esboço. Outro etnógrafo, com a mesma bibliografia e os mesmos informantes, construiria outra imagem. Fiz escolhas, tive lapsos voluntários e involuntários, estabeleci um ponto de corte temporal para a pesquisa, tenho gostos e me interessei mais por determinadas pessoas e narrativas que outras. Assim, aquilo que desenho é a imagem que escolhi desenhar a partir de peças de um quebra-cabeças, escolhidas no caminho da pesquisa. Este é um quebra-cabeças cheio de lacunas, borrões, pedaços turvos e nebulosos e imagens que faltam. Mas é o que tenho e, 
diante da peculiaridade daquilo que começarei logo a contar, acredito que tenha valor, tanto numa narrativa etnográfica quanto histórica.

Já que me dispus a contar dificuldades, a primeira e maior de todas é que, temporalmente, não estive lá. Lembro-me de estar numa academia de ginástica, a não muitos quilômetros de onde aquilo tudo acontecia, correndo numa esteira, quando, pela televisão, vi, pela primeira vez, ao vivo, as imagens veiculadas pela Rede Globo de Televisão, de homens fugindo pela mata, da favela da Vila Cruzeiro para o Complexo do Alemão. Não imaginei, ali, que, poucos meses depois, estaria envolvido num projeto de tentar entender o que estaria acontecendo naquele lugar.

Mesmo que lá estivesse e fosse, portanto, classificado como uma testemunha ocular, também sei que essa seria mais uma narrativa, e haveria outras, muito mais significativas que a de um, então, estudante de ciências sociais sonhando com o mestrado. Ainda que estivesse lá, pouco me aproveitaria já que o que aconteceu realmente dentro da Vila Cruzeiro e, logo depois, no Complexo do Alemão foi interditado a testemunhas civis de fora da favela e também à imprensa. Sabe como foi quem lá esteve seja como "ocupante"/"invasor" seja como morador "civil" ou "soldado do tráfico".

Não há nenhuma surpresa na constatação de que cada parte tem uma versão do evento e de que essas versões são bastante diferentes e, muitas vezes, contraditórias. Nem há espanto se aquilo que mais se precisa é justamente a imagem que falta. Esta não deixa de ser, portanto, uma etnografia da ausência, uma etnografia de uma imagem que falta. $\mathrm{O}$ acesso que tive ao que aconteceu se deu, então, por aquilo que aqueles que lá estiveram contaram. Esses tiveram tempo suficiente para, através da memória e seus processos, construir uma narrativa. Essas narrativas puderam, de forma consciente ou inconsciente, escolher aquilo que era para se lembrar ou esquecer. Meu papel foi o de selecionar algumas dessas narrativas e analisar seu discurso. Portanto, o que faço neste 
capítulo é analisar diferentes/divergentes discursos na forma de narrativas construídas a partir das memórias daqueles que foram testemunhas daqueles dias. Analisando, escolho, seleciono, comento e me posiciono. Esta é a forma que me aproximo do objeto.

Para Halbwachs (1990), em sua importante obra sobre a memória coletiva, o apelo aos testemunhos é para fortalecer ou debilitar, mas também para completar aquilo que sabemos de um evento que ainda se apresenta com questões obscuras. Assim, quando, além daquilo que sabemos ou lembramos, podemos nos apoiar na lembrança de outros, nossa confiança na exatidão dessa informação se torna maior. Mesmo que só nós estivéssemos envolvidos em algo, para esse autor, a memória sempre será coletiva porque nunca estamos sozinhos, já que temos sempre conosco e em nós uma quantidade de pessoas que não se confundem. Para melhor recordar, nós nos voltamos para elas, adotamos momentaneamente seu ponto de vista porque, de alguma forma, fazemos parte de um determinado grupo e encontramos em nós muitos pontos de vista e posições que jamais teríamos chegado sozinhos. Essa memória coletiva contribui para que se mantenha e se fortaleça a conexão com o grupo. Isso fica muito claro, por exemplo, quando, em algumas narrativas feitas por policiais, faz-se o tempo todo alusão ao grupo e a corporação é apresentada com forte marcação de quase literal corporalidade, possuindo uma memória coletiva de eventos trágicos ocorridos no Complexo do Alemão, ou relacionados a ele $^{1}$, e que, de alguma forma, ainda esperavam resposta ou vendeta. Assim como, na narrativa de alguns moradores, a polícia militar, especialmente o BOPE, é apresentado com forte carga de violência irracional, crueldade e desrespeito com moradores ao identificá-los numa totalidade como ou traficantes ou cúmplices destes.

\footnotetext{
${ }^{1}$ Por exemplo, um helicóptero da polícia abatido, segunda a polícia, a mando do traficante FB, um dos chefes do tráfico na região, alguns meses antes.
} 
Halbwachs (1990) vai afirmar que não basta que os depoimentos sejam trazidos para que nossa memória se auxilie com a dos outros, mas é preciso também que haja concordância e pontos de contato para que as lembranças possam ser reconstruídas sobre um fundamento comum. Logo, faz-se necessário um fluxo comum de concordâncias entre o indivíduo e o grupo ao qual pertence para que uma lembrança possa ser reconstruída e reconhecida. Portanto, não basta a reconstituição individual peça por peça. É fundamental que haja comunhão de memórias. O autor vai concluir que a dependência da memória coletiva é tanta que, mesmo quando atribuímos a nós mesmos as memórias, estamos tão afinados com aqueles que nos cercam que funcionamos como um eco. A memória individual seria, então, um ponto de vista sobre a memória coletiva, que muda conforme a posição que ocupo e conforme as relações que mantenho com outros meios. Assim, é marcada a natureza social da memória.

\section{Situação Social e Evento Crítico}

A escolha do evento da operação de ocupação militar do território do Complexo do Alemão, em novembro de 2010, como objeto de análise ocorreu porque considero este evento, ou conjunto de eventos, determinante para se compreender tudo aquilo que aconteceu depois, especialmente quanto ao projeto das unidades de polícia pacificadora e também porque vi neste evento quadros que explicitam uma forma contemporânea do estado brasileiro se apresentar àqueles que o "assistem" e lidar com certas populações que vivem às suas margens. Encontro naqueles dias mais do que uma simples operação militar, mas pistas importantes para se pensar temas mais profundos envolvendo aquelas instituições do estado.

Dois importantes conceitos foram determinantes para o tratamento que dei a este capítulo. 
O primeiro é o conceito de situação social, conforme talhado por Max Gluckmann (1987). Esse autor, em pesquisa realizada na Zululândia, descreve uma série de eventos observados num único dia, envolvendo a inauguração de uma ponte. As situações sociais, para ele, permitem abstrair a estrutura social, as relações sociais e as instituições de uma sociedade. Todos os eventos que descreve, observados em diferentes locais e com diferentes grupos, são interligados pela figura do observador. Ele define situação social da seguinte forma:

Portanto, uma situação social é o comportamento, em algumas ocasiões, de indivíduos como membros de uma comunidade, analisado e comparado com seu comportamento em outras ocasiões. Desta forma, a análise revela o sistema de relações subjacentes entre a estrutura social da comunidade, as partes da estrutura social, o meio ambiente físico e a vida fisiológica dos membros da comunidade (Gluckmann, 1987, p. 238)

Em sua análise, ele cita a cerimônia de inauguração de uma ponte, que reunia diferentes grupos com interesse comum naquele evento, o que fazia com que agissem num sistema de cooperação e comunicação, apesar das evidentes divisões e marcações da estrutura social. Naquela ocasião, o estado organizou e regeu a cerimônia de forma que tudo transcorresse sem conflitos - o que é significativo num período de fortes mudanças sociais.

De forma semelhante, destaco a ação de diferentes agências do estado em inédita cooperação com o objetivo de ocupar um território urbano de uma das mais importantes metrópoles do país. Apresentarei como isso se deu também numa forma ritualística, mas, ao contrário do que aconteceu na inauguração da ponte, o transcorrer dos eventos 
resultou em violento confronto armado e a possibilidade, talvez concretizada, de uma guerra com muitas vítimas.

O outro é o conceito de evento crítico, a quem devo crédito a Veena Das. Em sua obra Critical Events: an anthropological perspective on contemporary India (1995), a autora identifica certos momentos críticos na história da Índia contemporânea e os redescreve através do enquadramento do conhecimento antropológico. Sua definição de evento crítico, como uma qualificação de determinados eventos, envolve o fato de que, após tais acontecimentos, novos modos de ação vêm à tona e redefinem categorias tradicionais daquela sociedade. Os terrenos onde estes eventos se deram atravessaram diversas instituições, movendo-se através da família, da comunidade, da burocracia, dos sistemas judiciários, da medicina, do estado e das corporações multinacionais. No capítulo em que trata das mulheres sequestradas e seus filhos após a Partição da Índia, em 1947, a novidade foi que a racionalidade do estado e a racionalidade da família atravessaram-se mutuamente para criar uma única configuração de eventos quando essas mulheres foram reclamadas de volta.

\section{O que há de "novo" neste evento?}

Uma questão já pode ser feita a partir dessa proposta: como o Complexo do Alemão deixou de ser um problema local e se transformou num problema de proporções gigantescas que envolveu importantes interesses do estado? Como um problema de polícia, administrado por mais de duas décadas pelos governos do estado, se tornou um problema que "necessita" de uma coalisão de parte das diversas forças de segurança nacional para uma guerra que jamais aconteceu?

Historicamente, no Brasil, pelo menos nos últimos 150 anos, o exército é acionado ou se aciona em momentos de grave crise interna, seja real ou, na maioria das vezes, 
construído a partir do interesse de determinados grupos. Ao contrário do exército nacional de outros países, cuja principal missão é a proteção das fronteiras e os combates em países estrangeiros, no Brasil, essa instituição é acionada ou se aciona regularmente com vistas a uma ação político-militar dentro do território nacional a fim de combater determinados "inimigos internos", que são construídos como "ameaças à democracia".

Não foi, também, a primeira vez que o exército foi acionado para lidar com situações envolvendo o Complexo do Alemão. Todas essas situações envolviam algum tipo de evento internacional sediado na cidade. De alguma forma, o estado entendia ou que algo de muito ruim pudesse partir daquele território ou que melhor seria se aquelas populações faveladas permanecessem "presas" e "controladas" dentro de territórios circunscritos e não fossem protagonistas de nenhuma ação, violenta ou não, que pudesse ser noticiada, seja pela mídia nacional ou, especialmente, pela internacional, que circulava amplamente pela cidade.

Em 1992, durante a realização da conferência Eco92, as forças armadas ocuparam várias favelas cariocas, entre elas as do Complexo do Alemão. Ficaram notórias as imagens de tanques de guerra com seus canhões voltados para dentro das favelas.

Em 1994 e 1995, houve a chamada "Operação Rio", às vésperas das eleições presidenciais, quando o exército ocupou diversas favelas cariocas, entre elas as favelas do Complexo do Alemão. A comparação com os discursos dos agentes do estado e as representações midiáticas da época apresentam notável semelhança com o que ocorreu quinze anos depois.

O que, então, é "novo", de tal forma que se possa caracterizar este evento analisado como evento crítico? O exército brasileiro usado em uma grande operação numa metrópole urbana, de grande capital político e simbólico, e ocupando, posteriormente, um território relativamente grande dessa mesma cidade, com força de 
polícia e governo. Isso é novidade e estabelece uma forma de ação na militarização da segurança pública no Brasil; uma nova estratégia de ação do exército; uma nova sobreposição de governos daquele território, onde o estado (democrático) passa a governar através de seu braço armado, entre outras questões que serão percebidas ao longo deste trabalho. Isso tudo se deu porque "retomar" a hegemonia daquele território se tornou um problema, real ou construído, de segurança nacional.

\section{As Múltiplas Vozes}

Ao apresentar as narrativas e discursos daqueles que vivenciaram o evento adoto a ideia de "voz" ou "vozes" e não de "visão" ou "ponto de vista", assim concordo com Das (1995) de que o conceito de "voz" ou "vozes" é mais aberto ao caráter fragmentado e múltiplo da experiência social. Assim, o antropólogo deve aparecer não no papel de um observador, mas de um ouvinte que lida com aqueles que falam. Esses, por sua vez, saem da terceira pessoa e assumem a primeira pessoa do discurso numa narrativa corporificada, que é a única forma possível de se expressar um combate, uma humilhação ou um lamento. Esse é único caminho, segundo a autora, de resistirmos aos discursos totalizantes que surgem nas narrativas, tanto dos agentes do estado, quanto das organizações profissionais de conhecimento, mas também nos discursos de resistência que usam a mesma lógica do estado ao qual eles procuram resistir.

Quem são essas vozes? De tantas pessoas e grupos com quem estabeleci contato, algumas vozes se destacaram, não por falar aquilo que eu esperava ouvir, mas por terem se expressado mais e por suas trajetórias de vida serem significativas para este trabalho. O primeiro grupo é de moradores de diferentes áreas do Complexo do Alemão. O segundo grupo é de agentes do estado que, de alguma forma, participaram da ocupação/invasão. Para este grupo, escolhi usar seus textos escritos e publicados, que 
funcionam como uma espécie de discurso oficial. O contraste entre ambos os tipos de narrativas se tornará evidente.

Para o primeiro grupo, mudarei seus nomes e não farei referências que possam, de qualquer forma, prejudicá-los ou expô-los. Quanto ao segundo, usarei seus nomes reais e farei referências a suas memórias e narrativas que foram publicadas. Cada um destes e daqueles será apresentado conforme suas vozes forem aparecendo no texto.O terceiro grupo trata-se de veículos midiáticos de massa, como jornais impressos e online, telejornais e revistas, onde escolhi algumas reportagens que considerei emblemáticas para se entender a forma como a grande imprensa retratou o evento.

\section{A construção do cenário do espetáculo a partir da mídia e dos agentes do Estado}

Coronel Mario Sergio Duarte é Ex-Comandante Geral da Polícia Militar do Rio de Janeiro, esteve à frente de sua corporação durante os eventos narrados e em 2012 escreveu o livro: “Liberdade para o Alemão: O Resgate de Canudos”. Nele, traz suas memórias, em forma de narrativa, sobre o que aconteceu.

Na abertura da obra, na seção de Homenagens, no início do primeiro parágrafo diz: "Homenagem especial aos profissionais da mídia que não mediram esforços para transmitir imagens e informações fidedignas e esclarecedoras do teatro de operações ${ }^{2}$ : cinegrafistas, fotógrafos, jornalistas e auxiliares".

Sua homenagem já demonstra a existência de dois atores fundamentais na construção de todo espetáculo imagético que foi o evento de invasão/ocupação do Complexo do Alemão: a mídia ${ }^{3}$ e os agentes do estado. Escrevo esta seção já entregando

\footnotetext{
${ }^{2}$ Destaque meu.

${ }^{3}$ Com "mídia" não pretendo reificar e descorporificar o conceito, mas penso nos profissionais citados pelo próprio autor, especialmente aqueles vinculados à mídia de massa. Dou destaque especial aos veículos midiáticos ligados às organizações Globo, que fizeram a principal cobertura dos eventos. Principal não no sentido de melhor ou mais
} 
seu doce, o que não deixa de ser uma das conclusões deste capítulo e também da pesquisa: Houve uma cumplicidade peculiar entre os agentes do estado e os profissionais da mídia de massa, que cobriam os eventos da invasão/ocupação do Complexo do Alemão, quanto à construção das representações e categorias daquilo que foi a operação, de tal forma que o discurso oficial dos primeiros veio a se configurar como verdadeiro, atestado e corroborado pelos segundos.

Nesse sentido, o teatro de operações dos profissionais da imprensa não somente se afina ao, mas se torna o principal instrumento de espetacularização do teatro do estado em sua demonstração performática de exibição de poder e força, bélicas e simbólicas. Voltarei a essa questão mais adiante.

Tudo começa no dia 21 de novembro de 2010, quando alguns carros são incendiados na Linha Vermelha ${ }^{4}$ e também na zona sul da cidade. Isso se repete até o dia 24 daquele mesmo mês. No dia 23, a polícia faz operações em 20 favelas, onde prende 8 e mata 2 pessoas. No dia seguinte, a reação às ações policiais parece intensificar os ataques e registra-se oficialmente mais doze veículos queimados. Dessa vez a polícia prende 31 e mata 15 pessoas. Todas as 17 mortes teriam sido em confronto com "suspeitos". O dia seguinte, 25, marca o início da operação na Vila Cruzeiro, mas foram durante esses quatro dias que se constrói o cenário que desencadeia toda a espetacular operação no Complexo do Alemão.

Nos noticiários, o tom dramático é intensificado pelos títulos das reportagens: "Guerra no Rio: entenda o caso"5: "O governo do Estado já avisou que, apesar do clima de terror instaurado, não dará um passo atrás. De acordo com o governador Sérgio Cabral, trata-se de uma

apurada, mas como de maior alcance e com maior destaque durante sua programação, o que veio a elevar consideravelmente seus índices de audiência durante esse período.

${ }^{4}$ Importante via que liga o centro do Rio de Janeiro à Baixada Fluminense e ao Aeroporto Internacional Antônio Carlos Jobim.

${ }^{5} \mathrm{http}$ ://noticias.r7.com/rio-de-janeiro/noticias/-guerra-no-rio-entenda-o-caso-20101125.html, de 25/11/2010.

$3^{\text {RASILIANA- Journal for Brazilian Studies. Vol. 4, n.2 (2016). ISSN 2245-4373. }}$ 
reação desesperada dos criminosos"; "Terror no Rio de Janeiro: 27 de Novembro"6; "Guerra do Rio já dura 30 anos. E não vai acabar tão cedo"7; "Medo de ataques transforma a rotina do Rio"8; "Sérgio Cabral: 'Isso é uma guerra. E como em toda guerra você tem que reconquistar territórios"9; "Rio vive a quinta madrugada seguida de terror e carros queimados"10.

As capas do jornal "O Globo"11 foram um destaque à parte: Dia 22 de Novembro: "Guerrilha na Linha Vermelha"; dia 24: "Beltrame12: facções se uniram e reação da PM será em dobro"; dia 26: "O dia D da guerra ao tráfico"; dia 29: "O Rio mostrou que é possível". Desde o assassinato do jornalista Tim Lopes, empregado das organizações Globo, parece haver um sistemático investimento da emissora e seu jornal em construir uma representação do Alemão como o foco de todo o mal ${ }^{13}$. Significativo evento se deu durante a prisão do traficante Elias Maluco ${ }^{14}$, acusado do assassinato do jornalista, transmitido de forma espetacular por essa emissora, a única que pôde acompanhar a operação. Em programa

\footnotetext{
${ }^{6}$ http://veja.abril.com.br/multimidia/galeria-fotos/terror-no-rio-de-janeiro, em 27 de novembro de 2010.

${ }^{7}$ http://veja.abril.com.br/noticia/brasil/cenas-novas-numa-velha-guerra, em 27 de novembro de 2010.

${ }^{8}$ http://veja.abril.com.br/noticia/brasil/medo-impoe-mudanca-de-comportamento-no-rio-com-fechamento-de-escolase-comercio, em 24 de novembro de 2010.

9 http://veja.abril.com.br/noticia/brasil/sergio-cabral-\%E2\%80\%9Cisso-e-uma-guerra-e-como-em-toda-guerra-vocetem-que-reconquistar-territorios\%E2\%80\%9D, em 23 de novembro de 2010.

$10 \mathrm{http}: / /$ noticias.r7.com/rio-de-janeiro/noticias/rio-vive-a-quinta-madrugada-seguida-de-terror-e-carros-queimados20101126.html, em 26 de novembro de 2010.
}

11 Todas estas capas podem ser acessadas em : http://acervo.oglobo.globo.com/consulta-aoacervo/?navegacaoPorData $=201020101122$

${ }^{12}$ Referindo-se ao Secretário Estadual de Segurança, José Mariano Beltrame, gestor das UPPs, e capital político importante do governo de Sérgio Cabral. Sua candidatura às eleições governamentais foi seriamente planejada. Sua popularidade diminui muito após violentas ações policiais contra as manifestações e a greve de professores, em 2013, e após a forte veiculação midiática sobre o retorno do tráfico e dos confrontos armados em favelas "pacificadas". O Complexo do Alemão foi sempre um dos fatores determinantes do aumento ou queda da confiança no projeto de segurança Beltrame-Cabral.

${ }^{13}$ Alguns meses antes do novembro de 2010, a revista Caros Amigos havia feito uma crítica às coberturas de eventos policias no Alemão feitos pelo jornal "O Globo" em reportagem intitulada: "O Globo quer sangue". Disponível em: http://www.carosamigos.com.br/index.php/artigos-e-debates/745-o-globo-quer-sangue

${ }^{14}$ Cuja forma como se deu a operação traz fortes indícios da construção espetacular de um cenário para a imprensa.

RRASILIANA- Journal for Brazilian Studies. Vol. 4, n.2 (2016). ISSN 2245-4373. 
televisivo ${ }^{15}$, de caráter documental, exibido em 02 de abril de 2013, o famoso repórter Caco Barcellos, em tom acusatório, filmando no local onde o jornalista havia sido torturado e morto, pergunta a moradores: "O que vocês fizeram para evitar a morte do Tim Lopes? E, se não fizeram, por que não fizeram?". A suspeição de cumplicidade é evidente. Não somente por parte dele, mas de toda a emissora.

O uso constante das expressões medo, violência, pânico, terror e guerra pelas agências midiáticas se coaduna com os discursos dos agentes do estado. Duarte (2012, p.19), em suas memórias, afirma: "Ou agimos agora ou vira guerra civil!". O cenário parecia estar sendo bem construído. O inimigo comum estava lá: o Comando Vermelho: "Por anos o potencial de crime do CV fez o povo crer que o Rio era um lugar sem solução, uma cidade fadada a conviver com o poder paralelo se exibindo como instrumento de pressão" (Duarte, 2012, p. 37).

Leite (2000) aponta que a representação do Rio de Janeiro como uma cidade em guerra foi gestada a partir de uma série de eventos ocorridos na década de 1990 e que uma "metáfora da guerra" foi acionada sempre que eventos de violência pareciam se agravar, o que ocasionou a ideia de que o problema da violência exigia uma solução também violenta. As favelas seriam os eixos a partir dos quais toda violência e criminalidade da cidade sofria sua irradiação. Esta sociedade em crise não teria mais os instrumentos eficazes para lidar com esta situação que já fugiu a seu controle. Ela afirma que "parte da população carioca parece viver sob a metáfora da guerra, que vincula, de modo difuso, a criminalidade violenta e o narcotráfico às contradições que opõem morro e asfalto, traficantes e trabalhadores, favelados e cidadãos (Leite, 2000, p. 79).

No dia 29 de novembro, dois dias após a operação no Alemão, Duarte publica artigo no jornal O Globo, intitulado "Liberdade para o Alemão".

\footnotetext{
${ }^{15}$ Pode ser visto em: http://www.youtube.com/watch?v=9ypuKQhXnak
} 
“Uma observação atenta ao que tem se passado em nosso Estado, com destaque para as áreas onde estão localizadas as favelas, irá revelar que a evolução do medo abarca alguns vetores comuns aos conflitos armados, semelhantes aos ocorridos em países e territórios envolvidos em guerras internas, com significativo número de mortos entre contendores e inocentes... sem dúvida vivemos um conflito urbano armado. É menos do que uma guerra convencional, mas é muito mais do que um simples quadro de ordem pública que possa ser tratado com instrumentos convencionais ${ }^{16 \prime \prime}(2012$, p. 37)

O texto em destaque já aponta outro fator na construção deste cenário, neste caso, justificado a posteriori, que é a necessidade, segundo esse agente, do uso de instrumentos não convencionais. O que ele quer dizer é que o estado deve lidar com a situação do crime e da favela no Rio de Janeiro como num estado de guerra. Numa guerra, os direitos individuais são quase sempre suspensos e passa a vigorar o Estado de Exceção.

Rogério Greco, Procurador de Justiça do estado de Minas Gerais, André Monteiro, policial militar do BOPE, e Eduardo Maia Betini, policial federal, participaram de diferentes formas das operações de ocupação militar do Complexo do Alemão. Escreveram a três mãos, em 2013, o livro "A retomada do Complexo do Alemão". Monteiro abre o primeiro capítulo afirmando:

“Era um momento em que o povo carioca havia deixado sua alegria de lado. Os traficantes estavam impondo sua política de terror e a cidade estava em pânico. (...) Era assim que tudo funcionava e a cidade vivia amedrontada" (pp. 18, 19)

\footnotetext{
${ }^{16}$ Destaque meu.
} 
Betini continua:

“A população clama, desesperada, por uma intervenção enérgica do Estado" (p. 41)

"Fixei o olhar na TV, mas em minha cabeça passava um filme com as cenas dos locais os quais eu conhecia e que, em instantes, seriam novamente o palco de uma importante batalha do bem contra o mal" (pp. 42, 43)

O elogio à imprensa se dá também nesta obra:

\begin{abstract}
"Como em um reality show macabro, a nação acompanhou as ações das forças de segurança através de uma importante e bem-sucedida cobertura de imprensa" (p. 43)
\end{abstract}

Estava pronto o cenário que justificaria tudo que sucedeu e conquistou aprovação em massa da grande mídia e, consequentemente, de parcela considerável da sociedade carioca. Algumas observações já merecem ser feitas. Primeiro, percebe-se que a imprensa exerceu notável contribuição na constituição de todo este cenário de medo e terror. Não seria ingênuo em esperar, neste trabalho, que a mídia de massa exercesse uma função crítica nos processos da chamada "pacificação" das favelas cariocas, já que, historicamente, ela costumeiramente escolheu o lado da direita política e o comprometimento com certas elites políticas e econômicas, mas a forma como se mostrou a cobertura destes eventos foi efusivamente de apoio acrítico às operações dos agentes do estado, de tal forma que a cobertura jornalística se transformou numa propaganda 
do/de estado e suas ações ${ }^{17}$. As informações dadas por esses agentes transformavam-se imediatamente na verdade e o apoio às ações, mesmo as mais violentas, dos agentes do estado se apresentava de forma semelhante a dos eventos esportivos, quando se "torce" por algum dos times ou atletas. Não pretendo com isso acreditar no mito da imparcialidade ou esperar que haja apoio a qualquer tipo de ação criminosa, mas a forma como o cenário se construiu ofereceu apoio irrestrito a algumas instituições notoriamente violentas ${ }^{18}$ em ações bélicas contra territórios historicamente marginalizados e que, com frequência, sofreram/sofrem ações violentas e arbitrárias contra suas populações. Vale ressaltar que a "violência", a "brutalidade" e o "terror" foram atributos sempre associados à ação de traficantes que queimavam veículos ${ }^{19}$ e não à ação repressiva da polícia que, segundo dados oficiais ${ }^{20}$, mata 17 pessoas por dia no Rio de Janeiro, tendo atingido a proporção de um morto para cada dois presos em um dia. Assim como aconteceu em 2007, não se viu qualquer questionamento sobre a forma como as polícias cariocas estavam agindo para reprimir estas ações. Assim, a imprensa, especialmente a carioca e de grande circulação ${ }^{21}$, se coloca como uma aliada do estado não somente contra a criminalidade associada ao narcotráfico, mas também nas ações empreendidas por aquele na e contra a favela. Assim, conforme demonstramos, o elogio é mútuo.

17 Sobre o aumento da audiência na cobertura dos eventos referentes ao Complexo do Alemão: http://veja.abril.com.br/blog/radar-on-line/televisao/globo-retomada-do-alemao-e-da-audiencia/ http://veja.abril.com.br/blog/radar-on-line/televisao/guerra-do-rio-ao-vivo-rende-ibope-alto-para-a-globo/

${ }^{18}$ Como a polícia militar e a polícia civil carioca, especialmente suas tropas especializadas, o BOPE e o CORE, respectivamente.

${ }^{19}$ Não parece, em momento algum, que a ação destes grupos tenha tido por intenção vitimar pessoas que usavam estes veículos. Os veículos queimados estavam todos esvaziados.

${ }^{20}$ Dados não oficiais apontam um número bem maior de "autos de resistência”.

${ }^{21}$ As chamadas mídias alternativas e alguns outros veículos, sem tanta circulação e alcance, não devem ser incluídas nesta crítica.

RRASILIANA- Journal for Brazilian Studies. Vol. 4, n.2 (2016). ISSN 2245-4373. 
A segunda questão diz respeito à qualidade da informação apresentada pelos agentes do estado. Sabe-se, especialmente depois de Foucault, que o estado usa dados, estatísticas e outras informações produzidas por certas agências para gerir a máquina estatal e governar as populações. Essas informações são construídas -o que vai além da simplista ideia de manipulação- para justificar e legitimar as ações do estado no governo das populações. O que aconteceu no evento dos ataques foi a utilização em larga escala de informações que não tinham como ser provadas ou não tinham como ser dadas as fontes ou as formas como se chegaram àquelas conclusões, só restando àqueles que a recebiam confiar na autoridade do que a contava. Se, em alguns casos, operações policiais foram efetuadas após pesquisas, dados estatísticos de aumento de certos tipos de crimes em determinadas áreas ou filmagens e gravações investigativas, desta vez só restou a quem recebia as informações acreditar que, segundo aqueles que contavam, as informações eram fidedignas. Assim, precisou se acreditar que os mentores das ações eram Marcinho VP e Elias Maluco, que estavam presos e inacessíveis, e que o principal executor era o traficante FB, foragido. Aqueles que foram presos não poderiam contribuir muito com as investigações porque seguiam a lei do silêncio. A razão das ações contra o estado seria o processo de "pacificação" de algumas favelas da zona sul carioca, que estaria trazendo prejuízo considerável ao Comando Vermelho, e a transferência de traficantes presos para presídios federais. Por fim, a possibilidade de uma ação conjunta de diferentes facções criminosas em represália ao projeto do governo do estado, hipótese esta aventada em pronunciamentos do Secretário de Segurança, dos Comandantes da Polícia Militar e da Polícia Civil, e do Governador do estado.

A Terceira questão diz respeito a ação conjunta dos discursos destes agentes e o tom adotado pela imprensa para noticiar os eventos contribuiu para a construção de um cenário de terror que não somente justificaria mas necessitaria de saídas de emergência e estados de exceção.

$3^{\text {RASILIANA- Journal for Brazilian Studies. Vol. 4, n.2 (2016). ISSN 2245-4373. }}$ 
Agamben (2004) recuperou o diálogo entre Carl Schmitt e Walter Benjamim sobre o conceito de estado de exceção e apontou para a necessidade da construção de uma teoria do estado de exceção no direito público. É difícil defini-lo, segundo o autor, já que está estreitamente relacionado com a guerra civil, a insurreição e a resistência. Após apontar a Alemanha nazista como paradigma fundamental do conceito, destaca que “(...) a criação voluntária de um estado de emergência permanente (ainda que, eventualmente, não declarado no sentido técnico) tornou-se uma das práticas essenciais dos Estados contemporâneos, inclusive dos chamados democráticos" (2004, p. 13). Benjamin (Lowy, 2005, p.83) vai afirmar que "a tradição dos oprimidos nos ensina que o 'estado de exceção' no qual vivemos é a regra. Precisamos chegar a um conceito de história que dê conta disso". O estado de exceção transforma-se, assim, numa técnica de governo, uma prática duradoura e essencial dos eEstados contemporâneos, uma medida "ilegal", mas "perfeitamente jurídica e constitucional" que pode vir a se estabelecer como uma nova ordem jurídica (Agamben, 2004, p. 44). É uma tentativa de incluir na ordem jurídica a própria exceção, criando uma zona de indiferenciação em que o fato e o direito coincidem (Ibid., p.42).

Nas próximas seções, farei a sobreposição de diferentes narrativas sobre o que aconteceu na favela da Vila Cruzeiro. Agentes do estado, moradores e a mídia têm diferentes histórias. Ás Às vezes as narrativas se cruzam e se entrecortam, em outras parecem seguir caminhos radicalmente distintos. Na sobreposição fica evidenciada a diferença no olhar e na narrativa de cada um. Não pretendo comentar e apontar a todo momento as contradições e aporias porque o objetivo destas não é investigar para descobrir a verdade, mas evidenciar, em cada discurso, temas e apontamentos que já têm sido discutidos neste trabalho e outros que ainda virão a ser. Portanto, calo e deixo que estas vozes livremente narrem aquilo que poucas testemunhas realmente puderam contar. 


\section{O Horror Na Vila Cruzeiro}

No dia 25 de novembro, quinta-feira, cerca de 350 policiais iniciam uma grande operação na favela da Vila Cruzeiro, no bairro da Penha ${ }^{22} .150$ deles são do BOPE, e os outros 200, policiais militares de outros batalhões e policiais civis. A entrada aconteceu com o apoio da Marinha, que cedeu nove blindados. A justificativa da operação: a Vila Cruzeiro, segundo informações da inteligência da Secretaria de Segurança, seria o maior reduto dos traficantes responsáveis pelas ações criminosas que ocorriam na cidade. A ação começou por volta das $13 \mathrm{~h}$ e durou quatro horas.Ao fim da operação, dezenas de traficantes fogem por uma estrada de terra que liga a Vila Cruzeiro ao Complexo do Alemão. As imagens da fuga correm o mundo.

“Por volta das 15 horas, o tempo começou a fechar. Os traficantes resolveram voltar a efetuas efetuar disparos em direção às equipes do BOPE. Não sabiam, contudo, que várias equipes haviam ocupado os pontos altos e estratégicos" (Monteiro, 2014, p. 159)

Não é do escopo deste trabalho empreender a radiografia de uma batalha, mas um importante movimento do confronto, por motivos analíticos, merece destaque por ajudar a compreender melhor a fuga dos traficantes da Vila Cruzeiro para o Complexo do Alemão.Enquanto uma frente avançava rumo ao topo da favela, um grupo do BOPE adentrou por uma região chamada "matinha" e se posicionou em posições estratégicas. Aquela rota de fuga já era conhecida pelos policiais que fizeram operações no local e era

\footnotetext{
${ }^{22} \mathrm{O}$ saldo de mortos em confronto, antes da operação, já somava 26 pessoas. Entre eles, uma adolescente de 14 anos, vítima de um tiro nas costas.
}

RRASILIANA- Journal for Brazilian Studies. Vol. 4, n.2 (2016). ISSN 2245-4373. 
utilizada sempre que aconteciam operações na Vila Cruzeiro ou no próprio Complexo do Alemão. A "matinha" era a região mais densa de vegetação da rota de fuga. Ao se posicionarem lá o objetivo evidente seria o da emboscada e impedimento da fuga dos traficantes.

"As equipes do BOPE resolveram fazer uma linha única de fogo. Os traficantes passaram a fugir, amedrontados com a situação. Nesse momento, percebemos que partiram em direção às torres que faziam a divisa entre os complexos da Vila Cruzeiro e do Alemão. Os canais de televisão transmitiam, ao vivo, a ação da polícia. (...) Alguns desses traficantes já estavam feridos. As imagens mostravam muitos deles mancando (...) Fizemos uma linha de fogo mais intensa ainda. (...) (Monteiro, 2014, pp. 162, 163)

Durante a pesquisa, escutei algumas vezes narrativas de testemunhas e moradores sobre o que aconteceu na Vila Cruzeiro, inclusive de um daqueles que afirma ter sido filmado fugindo do BOPE. As descrições se assemelham ao descrito por Monteiro, pelo menos quanto aos movimentos do combate. Segundo algumas narrativas, a invasão da Vila Cruzeiro já havia sido negociada. O combinado seria que houvesse resistência até um determinado trecho, depois haveria a fuga de alguns e outros se entregariam. Os que fossem presos, receberiam toda assistência na prisão.

“Quando o primeiro grupo se entregou, o BOPE executou. Aí os outros que viram, fugiram" (Homem, 25 anos, morador) 


\begin{abstract}
“Tinha pra mais de cem corpos. Tudo empilhado. Eles saíram com tudo no caveirão ${ }^{23 \prime \prime}$ (Mulher, 25 anos, do lar, moradora)

"Quando o caveirão passou deixou um rastro de sangue pelo chão...pingava sangue dele" (Mulher, 40 anos, assistente social, moradora)
\end{abstract}

Uma importante liderança política local conta:
“Houve reforço dos soldados do CV lá do Juramento e do Engenho da Rainha... O que aconteceu aquele dia foi uma coisa de louco. Tem muita gente perdida até agora... Caveirão saiu com defunto."

João Lucas, filho de comerciantes da região, é pastor evangélico e liderança local. Conta que muitos membros de sua igreja tiveram ligação com o tráfico de drogas, alguns que frequentam o local de reunião ainda têm. Inúmeras vezes ele foi acionado para resgatar “condenados à morte" pelo tráfico. Sobre o dia da operação na Vila Cruzeiro, conta:

\footnotetext{
"Naquele dia morreu muita gente. No dia da invasão, o Bope tava na Matinha... mandaram parar de dar tiro por causa da televisão. Quem foi pela mata ficou. O cheiro era um negócio insuportável ...tinha urubus pra caramba. A imprensa foi proibida de subir (...) Os outros fugiram pelas obras do PAC."
}

\footnotetext{
${ }^{23}$ Referindo-se ao veículo de combate do BOPE.
} 
Durante a operação, um helicóptero da rede globo filma a fuga de traficantes rumo ao Complexo do Alemão. Em conversa com um oficial da polícia militar, que chegou a comandar o policiamento no entorno do evento, ele diz:

"Se você olhar o iniciozinho das filmagens, você vai ver. O BOPE tá atirando da matinha. O helicóptero da civil também. A ordem era atirar e matar todo mundo. Aí apareceu o helicóptero da globo. Na hora o comandante mandou cessar fogo"

Realmente, no início da transmissão, pode-se ver que os traficantes estão sendo alvo de tiros. Após algum tempo de transmissão, os tiros cessam. Na página oficial do BOPE na rede social Twitter, um comentário significativo: “Um desserviço prestado pelas aeronaves da Record e Globo". O serviço de comunicação da Record respondeu prontamente: "Estamos fazendo a cobertura jornalística de fatos graves e não recebemos nenhum pedido ou comunicação da Secretaria de Segurança Pública do Rio para deixar de filmar alguma coisa". No dia seguinte à polêmica, a mesma assessoria de imprensa da Polícia Militar que havia confirmado ao jornal Folha de São Paulo a autenticidade do perfil na rede social, afirma, então, que ele é falso. O Secretário de Segurança diz que "o Bope tem pessoas muito técnicas e especializadas naquilo que fazem, então podem ter tido outra interpretação". A Globo não se manifestou, já que o perfil seria falso ${ }^{24}$.

Se o objetivo das filmagens era elevar a audiência e enriquecer a cobertura jornalística, no tom de espetáculo, conforme desde o início se apresentou, seu resultado indireto parece ter sido o de ter evitado uma chacina- ou uma chacina ainda maior. Fica evidente que a crítica do BOPE às filmagens foi desmentida após ter repercutido mal.

${ }^{24}$ Essa polêmica pode ser encontrada em: http://www.correiodoestado.com.br/noticias/pm-do-rio-nega-critica-dobope-pelo-twitter-a-cobertura-das_87427/, em 26 de novembro de 2010. 
Afinal, por que aquelas imagens não poderiam ter sido mostradas? $O$ que havia acontecido que não poderia ser publicizado? O que elas impediram de acontecer? Ao que tudo indica, desde a proibição do acompanhamento da operação por jornalistas e observadores externos, a falta de documentação imagética da mesma e os testemunhos obtidos, a operação foi mais brutal e sangrenta do que as narrativas oficiais levam a crer. Estava instalado o mais puro estado de exceção onde a gestão da vida e da morte estava nas mãos das polícias. Suspenso o direito, a administração da morte e da violência letal vai além da legítima defesa e da destruição do inimigo que ataca e resiste com violência. Aqueles que fugiam, que nas palavras do comandante da PM, eram como "hordas molambentas que se apressaram em fuga denunciadora de uma coragem fraudulenta, fantasiosa, vagabunda" (Duarte, 2012, p. 103), construídos como a corporificação de todo o mal e a maior de todas as ameaças à democracia, eram como erva daninha que precisaria ser extirpada do mundo. Muito além de toda gigantesca e bilionária rede de relações do narcotráfico e do tráfico de armas que envolve largo capital político, envolve cúpula de todas as polícias militares, civis e federais e políticos, militares e empresários de ampla circulação e divisas espalhadas por diferentes paraísos fiscais, o ódio e a vingança por todo este estado de coisas- a droga e a arma-, é expiado no indivíduo negro, favelado, empobrecido, marginal, de fuzil na mão. Estes são vida nua, como a antiga figura do direito romano relembrada por Agamben (2010), o Homo Sacer, a vida matável, indigna de ser vivida. Aquele que os matar não será considerado culpado de homicídio.

\section{O Espetáculo Do Estado}

Mário Sérgio Duarte, Comandante da Polícia Militar: 
“Enquanto aguardava os jornalistas, fiquei assistindo a transmissão da saída do grande comboio misto de Fuzileiros e PMs em direção às cercanias da Vila Cruzeiro.

Era uma imagem inesquecível.

Uma coluna de caminhões com equipamentos militares formada por gente decidida a fazer história, se deslocava imponente na Rodovia Washington Luiz. (Soares, 2012, p. 89)

“Veículos blindados da Marinha do Brasil eram movimentados em um espetáculo observado a poucos metros por uma população que, finalmente, conheceria o verdadeiro poder do Estado e para a qual seria apresentado o conceito do Estado Democrático de Direito ${ }^{25}$. Mas não sem as agruras do combate. Antes de devolver o Complexo do Alemão para os mais de 400 mil habitantes, as forças de segurança precisariam extirpar do tecido social aquele mal denominado tráfico de drogas, ao menos seu poder bélico deveria ser reduzido de forma a prostrar seu ímpeto criminoso de joelhos diante das forças de segurança" (Betini, 2014, p. 78, 79)

Na tarde do dia 25 de novembro, o governador Sérgio Cabral envia ofício ao Ministério da Defesa solicitando a cessão temporária de 600 militares das Forças Armadas e diversos equipamentos bélicos. A autorização acontece no mesmo dia, através do Presidente Luiz Inácio Lula da Silva e do ministro da defesa Nelson Jobim. Nos dias 26 e 27, acontece o deslocamento de tropas e equipamentos e a preparação para a operação de invasão/ocupação do Complexo do Alemão. Polícia Civil (CORE), Polícia Militar

${ }^{25}$ Grifo meu.

3RASILIANA- Journal for Brazilian Studies. Vol. 4, n.2 (2016). ISSN 2245-4373. 
(BOPE), Polícia Federal (Comando de Operações Táticas), Exército Brasileiro (Brigada Paraquedista) e Marinha do Brasil formam as chamadas forças de segurança que realizariam a operação. Nestes Nesses dois dias, os lentos deslocamentos de policiais e militares para a região, a espetacular exibição de poderio bélico, acompanhada com tom ufanista pela imprensa, formaram um ritual de exibição de poder e glória pelo estado brasileiro. Esta Essa exibição não teve como plateia os traficantes que supostamente estariam se preparando para a guerra, mas a população que assistia ao espetáculo das ruas e, principalmente, pela televisão, em todo território nacional, e até fora dele.

Geertz (1980), em sua análise do estado teatro em Bali no século XIX, demonstra que o culto do estado é um argumento, sempre repetido através da linguagem do ritual, de que o status mundano tem uma base cósmica onde a hierarquia é o princípio que rege o universo. Para ele, status é tudo. As extravagâncias rituais do estado teatro são como a expressão simbólica não tanto da grandeza do campesinato, mas da sua ideia do que a grandeza é. De forma semelhante, transponho esta análise ao cenário urbano de uma grande metrópole e penso que o princípio é o mesmo. As extravagâncias e todo exibicionismo de poder e glória executados pelo estado brasileiro dependem, em sua construção e nas partes do ritual, da ideia do que a grandeza é, especialmente para uma nação em desenvolvimento econômico e palco dos mais importantes megaeventos esportivos mundiais, Copa do Mundo de futebol e Olimpíadas, além de outros como Copa das Confederações, Copa América, Jornada Mundial da Juventude, etc.. Mas há um diferencial: só se pode entender esta exibição, no século XXI, se levar-se for levado em consideração que este teatro não foi só exibido para aqueles que estiveram fisicamente presentes, mas alcançou o mundo todo, através de toda uma outra forma própria de linguagem, a da televisão e, quiçátalvez no futuro, do cinema, e alcançou o mundo todo. . 
Assim, torna-se muito útil a análise de Debord (1997), onde "toda a vida das sociedades nas quais reinam as modernas condições de produção se apresenta como uma imensa acumulação de espetáculos. Tudo o que era vivido diretamente tornou-se uma representação" (1997, p. 13). Para este esse autor, o espetáculo apresenta-se ao mesmo tempo como a própria sociedade, uma parte dela e instrumento de unificação. Ele não é um conjunto de imagens, mas uma relação social entre pessoas, mediada por imagens (Ibid., p. 14). É a afirmação da aparência e a afirmação da vida humana como simples aparência (Idem, p. 16). Portanto, nessa sociedade fundamentalmente espetaculoísta (Ibid., p. 17), que tem como o espetáculo sua principal produção, onde ocorre o deslizamento do ter para o parecer, este teatro do estado brasileiro precisou ser construído na forma de um espetáculo a fim de ser exibido para milhões de pessoas que encontrariam no espetáculo que assistiam, e do qual fundamentalmente fazem parte, a confirmação dramática de pertencimento e adesão ao estado que administra suas vidas.

Este espetáculo se desenrola de forma essencialmente ritual. Desde Durkheim (1989) sabemos que os ritos são "maneiras de agir que surgem unicamente no seio dos grupos reunidos e que se destinam a suscitar, a manter ou a refazer certos estados mentais desses grupos" (p. 38). Em sua genealogia, ele encontra na religião a origem das categorias. Mesmo secularizados, estes rituais de guerra e exibição de poder e glória empenhados pelas instituições em jogo, numa performance coletiva, têm sua forma e origem em questões metafísicas sendo, assim, possuidores de um caráter religioso. Carl Schmitt (2009) já havia apontado que todos os conceitos decisivos da moderna doutrina do Estado estado são conceitos teológicos secularizados.

Debord (1997) percebeu a relação entre o espetáculo e a religião quando afirmou que a filosofia, como poder do pensamento separado e pensamento do poder separado, jamais conseguiu superar a teologia. Sendo assim, “o espetáculo é a reconstrução material da ilusão religiosa" (p. 19). O estado teatro geertziano e a sociedade de 
espetáculo contemporânea têm em comum a exibição e a concretização terrena da hierarquia. "Assim, o espetáculo é uma atividade especializada que responde por todas as outras. É a representação diplomática da sociedade hierárquica diante se si mesma, na qual toda outra fala é banida" (Debord, 1997, p. 20).

Chama a atenção, mais uma vez, como estes agentes do estado, em suas narrativas oficiais, mesmo que na forma de memórias, descreveram aqueles eventos:

“A população queria ver e fotografar os "tanques de guerra: corcéis de metal que quase atropelaram, a galope de esteiras, as hordas molambentas que se apressaram em fuga denunciadora de uma coragem fraudulenta, fantasiosa, vagabunda. Queria conferir a majestade dos tigres encouraçados que, quais bichos-papões pósmodernos, puseram a correr, apavorados como coelhinhos sujos, os estorvos da sociedade pacífica que a Vila Cruzeiro poderia ter sido sempre, se aquelas falanges malévolas de sandálias de dedo esbagaçadas e cordões de ouro em pescoços encardidos não lhes tivesse subtraído tanta vida e tanto futuro por vinte e cinco anos." (Soares, 2012, p. 103)

"Aquela fila enorme de blindados, se deslocando pela avenida Brasil era uma demonstração de força do Estado jamais vista" (Monteiro, 2014, p. 156)

“Nas calçadas, centenas de pessoas assistiam, atônitas, ao espetáculo de força proporcionado pelo Estado." (Betini, 2014, p. 204) 
“Sim, nossa nação, porque estava em jogo não o tráfico de drogas e o domínio de territórios por esses traficantes na cidade do Rio de Janeiro. Mais do que isso, estava em jogo a força do próprio Estado, como um todo" (Greco, 2014, p. 235)

Assim como em Negara, tudo isto era mise-en-scène e através dela, dos rituais de corte, que Negara se tornava viva e existente (Geertz, 1980, p. 116), pelo espetáculo de força e exibição de poder bélico o estado brasileiro se torna vivo e real para aqueles que o assistiram.

Esste autor aponta que o substantivo mestre do moderno discurso político, estado, tem ao menos três temas etimológicos condensados nele. O primeiro é status, no sentido de posição, condição; o segundo é pompa, no sentido de esplendor, exibição, dignidade; o terceiro é governo, no sentido de reinado, regime, domínio, senhorio. O último destes significados, mesmo sendo o mais recente, acabou obliterando nossa compreensão da multiplicidade da natureza da alta autoridade. O que Negara faz, segundo ele, é explicitar a interconexão entre status, pompa e governo, exatamente aquilo que o conceito contemporâneo de poder público obscurece.

As visões do estado como "grande besta", do Leviatã de Hobbes ao Minotauro de Jouvenel, localizam seu poder no caráter ameaçador do dano, assim a função da parada e da cerimôonia da vida pública seria disseminar o terror naqueles que ameaçam o confronto. Nas visões do estado como "grande fraude", de Marx a Pareto, a concepção de cerimônia do estado é mais uma mistificação, no sentido de espiritualização de interesses materiais e obscurecimento dos conflitos materiais. Em todas esstas visões, segundo Geertz (1980), o aspecto semiótico do estado acaba sendo uma pantomina. A cultura clássica balinesa permite ao autor uma outra visão da teoria política, onde o status é sua obsessão dominante e o esplendor é o material do estado. Para se entender 
negara é preciso deslocar suas emoções e construções para estes atos que elaboram uma poética do poder, não uma mecânica. Assim, o estado emana sua força, que é suficientemente real, de suas energias imaginativas, sua capacidade semiótica de fazer da desigualdade algo encantador. O motor de tudo isto são as cerimônias do estado.

Agamben (2011), numa análise de admirável fôlego teórico, propõe encontrar no dispositivo da oikonomia da doutrina da trindade cristã um laboratório privilegiado para observar o funcionamento e a articulação da máquina governamental, ou seja, a forma que o poder assumiu no Ocidente como um governos dos homens. Para ele, a dupla estrutura da máquina governamental assume uma "forma da articulação entre Reino e Governo e, por fim, questiona a própria relação (...) entre oikonomia e Glória, entre o poder como governo e gestão eficaz e o poder como realeza cerimonial e litúrgica" (p. 10). A relação entre oikonomia e Glória assume a estrutura última da máquina governamental do Ocidente. Ele encontra na forma moderna da opinião pública e do consenso a função das aclamações e da Glória. Os meios de comunicação assumem, então, função primordial nas democracias modernas porque, principalmente, administram e dispensam a Glória, “aquele aspecto aclamativo e doxológico do poder que na modernidade parecia ter desaparecido" (p. 10). Em diálogo com Debord: “A sociedade do espetáculo é, desse ponto de vista, uma sociedade em que o poder em seu aspecto "glorioso" se torna indiscernível com relação à oikonomia e ao governo" (p .10). A mídia difunde e dissemina em cada âmbito, público e privado, da sociedade este aspecto da glória, onde antes havia o confinamento às esferas das liturgias e dos cerimoniais. Agamben conclui: "A democracia contemporânea é uma democracia inteiramente fundada na glória, ou seja, na eficácia da aclamação, multiplicada e disseminada pela mídia além do que se possa imaginar (p. 278).

3RASILIANA- Journal for Brazilian Studies. Vol. 4, n.2 (2016). ISSN 2245-4373. 


\section{A guerra que nunca houve}

No dia 28 de novembro, um domingo, às $8 \mathrm{~h}$ da manhã, começa a operação de ocupação/invasão do Complexo do Alemão, com cerca de 2.600 agentes de segurança. Pouco mais de uma hora depois, o comandante da PM anuncia a vitória ${ }^{26}$. Alguns tiros são ouvidos. Nada que se compare ao que aconteceu na Vila Cruzeiro. A batalha do Alemão não aconteceu. A guerra nunca houve, mas há muito para ser dito. Palavras do comandante da PM:

“Os bandidos haviam sumido! (...) Quase não havia reação!” (Duarte, 2012, p. 146)

"A sangrenta batalha prevista para o Complexo do Alemão nunca aconteceu" (Ibid., p. 151)

À noite deste desse mesmo dia, o Secretário de Segurança, fala em entrevista coletiva e classifica o Complexo Alemão como o "coração de todo o mal" e que seu mito era derrubado ${ }^{27}$.

Outras vozes surgem ${ }^{28}$. Surpreendentemente dissonante com o veículo onde escreve e com o tom da mídia de massa, o repórter Jorge Antônio de Barros, o chamado

\footnotetext{
${ }^{26}$ Teriam sido apreendidos, segundo seu relato, 37 toneladas de maconha, 169 fuzis, 215 pistolas, 19 carabinas, 34 espingardas, 39 metralhadoras com bi-pé, 19 submetralhadoras, 77 revólveres, 418 quilos de cocaína, 5,2 quilos de haxixe, 161 quilos de crack, 300 motos e 50 carros.

${ }^{27}$ http://oglobo.globo.com/pais/noblat/posts/2010/11/28/beltrame-derrubado-mito-do-complexo-do-alemao344987.asp

${ }^{28} \mathrm{Na}$ Veja, o colunista Reinaldo Azevedo fala sobre o acordo com os traficantes para que a ocupação fosse pacífica: http://veja.abril.com.br/blog/reinaldo/geral/o-acordo-a-ocupacao-pacifica-do-complexo-do-alemao-e-o-futuro/
} 
"repórter de crime" do "O Globo", levanta, em seu blog, vinculado a este esse jornal, suspeitas sobre a operação:

“Não quero ser do contra em hipótese alguma, mas meu trabalho é mesmo o de colocar pulgas atrás das orelhas de vocês. Não tenho qualquer informação, posso estar totalmente enganado, mas há sinais claros de que houve algum tipo de acordo nos bastidores para que a maioria dos bandidos deixasse o território, sem a reação esperada pela sociedade. (...)

O comandante-geral da PM, coronel Mário Sérgio, está convencido de que os criminosos permanecem escondidos no Alemão. O cerco do exército foi muito bem feito, mas na operação da Vila Cruzeiro há suspeitas de que policiais ajudaram os bandidos a escapar levando R\$ 2 milhões naquela picape que apareceu nas imagens da fuga em massa." 29

Algumas vozes locais também o fazem:

"O que eu vou falar todo mundo sabe. Os principais pagaram pra sair e saíram escoltados. O FB pagou 2 milhões ...Pezão pagou 5 milhões...

Fui pego na Nova Brasília. Viram nada consta e me liberaram. Botaram fuzil na minha cara, me xingaram. Policial entrou na minha casa várias

29 http://oglobo.globo.com/rio/ancelmo/reporterdecrime/posts/2010/11/28/moradores-do-alemao-colaboram-comforcas-de-seguranca-344880.asp 
vezes. Bateram em mulher. Roubaram casa. Levaram dinheiro. Por doze anos, policial botou fuzil na minha cara.

Se falasse ou reclamasse diziam que tava protegendo traficante." (Vagner)

Sidnei relatou que ficou com medo por sua família. Sua esposa teria insistido em ficar já que ele ficaria, acompanhando eventuais emergências, especialmente por causa dos membros de sua igreja. Depois de muita insistência, na manhã da invasão, ele tenta sair de uma das principais ruas da favela, onde reside, mas é impedido por um militar.

“Os chefes no dia da invasão saíram numa boa. Eu não podia sair de casa. Mandaram eu voltar. Mostrei minha filha pequena e disse que ela tava com fome e eu precisava ir ao mercado pra comprar mantimento...tava tudo fechado por lá. Ele deixou eu sair e disse pra procurar ele na volta"

Conta, então, que deixou sua família na casa de seu sogro e retornou. Estava tão nervoso que esqueceu de comprar comida. Ficou dentro de casa por dois dias, comendo miojo, esperando a situação se acalmar. Só saía para ir à igreja, que ficava alguns metros à frente de sua casa. De lá recebia pessoas, ligações, e escutava o que estava acontecendo. Conta ter escutado sobre torturas e execuções. Numa outra igreja, um grupo de policiais teria invadido e roubado as ofertas.

"Cinquenta reais, meu irmão". 
"Roubaram muita coisa da casa das pessoas. Eles entravam e pediam nota fiscal. Quem guarda isso? Se não tivesse levavam tudo. Eletrodoméstico, joia, celular, moto, qualquer coisa..."

“Entraram na casa do meu vizinho. Disseram que receberam denúncias que ali tinha droga e arma escondida. Era o que eles diziam pra entrar na casa de todo mundo. O cara era trabalhador. Conheço ele desde pequeno. $\mathrm{O}$ cachorro dele tava preso na corrente e não parava de latir. $\mathrm{O}$ policial deu um tiro na cabeça do cachorro."

Mateus:

“Caveirão saiu com muita gente grande... Usaram de truculência. Foram agressivos. Furtaram os outros. Ouro, prata, tudo que tinha valor...levaram. O Bope tinha carta branca de fazer a limpeza geral ...execuções, torturas, agressões, forjaram muitas situações em cima das pessoas"

João Lucas:

"Quem tinha ouro para sair pagou e saiu do morro"

Se a batalha não aconteceu, o vencedor, contudo, se viu no direito de usufruir dos despojos do exército vencido. Após a ocupação estratégica do território, era preciso "varrer" as casas, em busca de armas e drogas. Ao que parece, para estes esses agentes do estado, toda casa é potencialmente suspeita de colaboração com o tráfico, até que se prove o contrário. Estabelece-se o mais puro estado de exceção e os domicílios não se 
tornam mais redutos invioláveis do âmbito privado do cidadão. Muitas vozes locais resistem, mas não são ouvidas. A mídia noticia denúncias de roubos e saques feitos por policiais, mas a violação de domicílio é naturalizada tanto pela imprensa, quanto pelos agentes do estado e, por impotência ou falta de informação, pelos moradores. O que chama a atenção, nesta nessa situação, é que o direito é suspenso, sendo estabelecido um outro ordenamento jurídico, com suas regras próprias. Sem constrangimento algum, devido, penso, à naturalização do procedimento, os agentes do estado se pronunciam sobre o que precisou ser feito após a ocupação.

"Agora todos os dois complexos voltariam para as mãos do Estado. Isso era inevitável e os traficantes também sabiam disso. Mas, antes, tínhamos que fazer um pente-fino em todo território já conquistado. $\mathrm{O}$ trabalho seria intenso, pois teríamos que varrer cada pedaço, cada residência, cada buraco, enfim, teríamos que começar uma busca em, aproximadamente, $454.000 \mathrm{~m}^{2 \prime \prime}$ (Monteiro, 2014, p. 178)

"Continuamos o trabalho de "bater as casas", ou seja, entrar nos barracos buscando traficantes, drogas, armas ou munição." (Betini, 2014, p. 213)

Logo começaram a surgir denúncias ${ }^{31}$ de que as "varreduras", em muitos casos, se transformavam também em saques, agressões, depredações e torturas. Muitos moradores, tendo que deixar suas casas para trabalhar, deixavam papéis colados nas

\footnotetext{
${ }^{30} \mathrm{O}$ capítulo inteiro de onde extraí este trecho chama-se "A varredura".

${ }^{31}$ http://oglobo.globo.com/pais/noblat/posts/2010/11/29/alemao-policiais-poderao-ser-expulsos-por-saques345308.asp e http:/veja.abril.com.br/blog/veja-acompanha/violencia-no-rio/moradores-denunciam-abuso-depoliciais-beltrame-promete-punicao/, por exemplo.
} 
portas pedindo que suas casas não fossem arrombadas. Quando questionado sobre isso, o governador Sérgio Cabral, em entrevista coletiva ${ }^{32}$, disse que "não vai tolerar abusos", que os policiais pegos seriam punidos. Conclui sua fala, entretanto, dizendo que se tratava de uma "guerra".

Encerro este artigo descrevendo uma cena ocorrida na primeira visita do Secretário de Segurança Pública, José Mariano Beltrame, ao Alemão, após a ocupação das tropas ${ }^{33}$ : acompanhado do comandante da Polícia Militar, Mario Sergio Duarte, cercado de dezenas de policiais e repórteres de jornais e televisões, o secretário caminha em tom triunfante. Flashes, closes, aplausos eram são oferecidos em profusão. A comitiva é interrompida por uma moradora, Dona Cleonice, 54 anos, empregada doméstica. Ela reclamava que não estava podendo sair para o trabalho. Conta que, no dia anterior, um policial entrou em sua casa: "Um policial entrou e quis saber onde tinha paiol, onde tinha traficante, e eu disse que não sabia. Eu trabalho, não passo o dia aqui". O policial teria pego na arma, reagindo a um bule de água quente que estava com ela, e a ameaçado, querendo levar todo o dinheiro que ela tinha em casa- cerca de 2.400 reais. Depois levou embora um cacho de bananas. "Saiu comendo", completoucompleta.

\section{Referências Bibliográficas}

Agamben, Giorgio. O reino e a glória: uma genealogia teológica da economia e do governo: homo sacer, II, 2. Tradução de Selvino J. Assmann. São Paulo, Boitempo, 2011. Estado de exceção. Tradução de Iraci D. Poleti. 2ª . Ed. São Paulo, Boitempo, 2004.

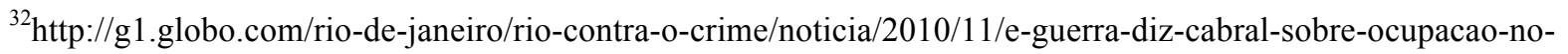
alemao.html

${ }^{33}$ Este evento me foi contado algumas vezes por testemunhas que viram o evento e também pode ser encontrado em: http://veja.abril.com.br/blog/veja-acompanha/violencia-no-rio/moradora-denuncia-diretamente-a-beltrame-abuso-depolicial/
} 
Das, Veena. Critical Events: an anthropological perspective on contemporary India. Nova Delhi, Oxford University Press, 1995.

Debord, Guy. A sociedade do espetáculo. Tradução de Estela dos Santos Abreu. Rio de Janeiro, Contraponto, 1997.

Duarte, Mario Sérgio. Liberdade para o Alemão: O Resgate de Canudos. Rio de Janeiro, Ed. Ciência Moderna Ltda., 2012.

Durkheim, Émile. As formas elementares da vida religiosa. Tradução de Joaquim Pereira Neto. São Paulo, Paulus, 1989.

Geertz, Clifford. Negara: the theatre state in nineteenth-century Bali. New Jersey, Princeton University Press, 1980.

Gluckman, Max. Análise de uma situação social na Zululândia moderna. In Bela FeldmanBlanco (org.). Antropologia das sociedades contemporâneas. São Paulo, Global, 1987.

Greco, Rogério. A retomada do Complexo do Alemão / Rogério Greco, André Monteiro, Eduardo Maia Betini. Niterói, RJ, Impetus, 2014.

Halbwachs, Maurice. A memória coletiva. Tradução de Laurent León Schaffter. São Paulo, Editora Revista dos tribunais, 1990.

Leite, Márcia. Entre o individualismo e a solidariedade: dilemas da política e da cidadania no Rio de Janeiro. Revista Brasileira de Ciências Sociais. Vol. 15, n. 44, 2000.

Lima, Carlos Alberto de. Força de Pacificação: Os 583 Dias da Pacificação dos Complexos da Penha e do Alemão. Rio de Janeiro, Agência 2a Comunicação, 2012.

Löwy, Michael. Walter Benjamin: aviso de incêndio: uma leitura das teses "Sobre o conceito de história". Tradução de Wanda Nogueira Caldeira Brant, Jeanne Marie Gagnebin e Marcos Lutz Müller. São Paulo, Boitempo, 2005.

Schmitt, Carl. Teología política. Tradução de Francisco Javier Conde. Madrid, Editorial Trotta, 2009. 